$\xi=$

\title{
Vermiconversion of paper industry waste for recycling the nutrients usig earthworm eudrilus eugeniae kingberg on growth of cluster bean (cymopsis tetragonoloba)
}

\author{
P. Sivakumar *, R. Chithra \\ Department of Biology, Gandhigram Rural Institute - Deemed University, Gandhigram-624 302, Dindigul Dist, Tamil Nadu, India \\ *Corresponding author E-mail: sivak2067@gmail.com
}

\begin{abstract}
Objective: To preparation of vermicompost from paper industry waste for recycling the nutrients using earthworm Eudrilus eugeniae kingberg. To analyze the physico chemical parameters of vermicompost, vermiwash and vermicompost extract, enumeration of microorganism from vermicompost, growth parameters and biochemical characteristics of Cluster bean (Cymopsis tetragonoloba) were studied. Methods: The paper industry wastes washed for two times with preparing the predecompost and it kept in 30 days. For preparing the vermicompost, the predecomposition was directly mixed with cowdung in the ratio of 1:2 on dry weight basis in same tank. Seventy number of healthy, clitellate Eudrilus eugeniae kingberg were introduced in the same tank. After 45 days the trial tank compost were sieved and collected for paper industry waste vermicompost.

Results: The physico chemical parameters of vermicompost vermiwash and vermicompost extract were studied, the growth parameters and biochemical characteristics were higher in treatments 5 and 6 of Cluster bean were using various concentration of vermicompost, vermiwash and vermicompost extract.

Conclusion: Present study was concluded that the Eudrilus eugeniae kingberg is more efficient in bioconversion of paper industry waste vermicompost, vermiwash and vermicompost extract were using various concentration of pot culture study of brinjal was higher growth and high yield and vermicompost act as an excellent biofertilizer of crop plants.
\end{abstract}

Keywords: Vermicompost; Vermi Wash; Vermicompost Extract; Physico Chemical Parameters; Growth and Biochemical Parameters.

\section{Introduction}

Presently many cities are facing the problem of disposal of solid waste generated within the cities. Solid waste arising out of domestic, commercial industrial and agriculture products comprises biodegradable (organic) and non-biodegradable material. Paper industry of India is the $15^{\text {th }}$ largest industry in the world and contributes 5 million dollars to the government's coffer annually. This will not only severely pollute land and ground water of that area but there will also be a waste of rich carbon resource (Nirmala Natarajan and Gajendran 2014). Disposal and environmental friendly management of these industrial wastes has become a serious global problem. Contamination of ground water, soils, as well as, food resources are some of the problems which have resulted from land filling practices of dumped waste materials.

The safe treatment and recycling of solid pulp and paper mill sludge (SPPMS) emerging out of effluent treatment plants mixed with cow dung (CD) and food processing waste (FPW) to produce good quality compost using vermitechnology (Nogales et al., 2005). The use of earthworms in the degradation of various types of wastes is continuing from the past so many years. These wastes include industrial, agricultural and domestic wastes etc. This study examines the potential of the African night crawler Eudrilus eugeniae in the vermicomposting of waste paper (Muddasir Basheer and Agrawal 2013). Vermicompost is rich in NKP (nitrogen 2-3\%, potassium $1.85-2.25 \%$ and phosphorus $1.55-2.25 \%$ ), micronutrients, and beneficial Soil microbes and also contain 'plant growth hormones \& enzymes'. It is scientifically proving as 'miracle growth promoter \& also plant protector' from pests and diseases. (Gajalakshmi et al., 2002). The work related to the preparation of predecompost with vermicompost, preparation of vermiwash and vermicompost extract, physico chemical parameters, growth parameters and biochemical characteristics of cluster bean is total wanting. Hence the present study was carried out.

\section{2. materials and methods}

The paper waste sample was washed with water for two times. For the first wash, one kilogram of paper waste was washed with two liters of water and for the second wash, one liter of water was used and the paper waste was shade dried for a day, for preparing the predecompost the paper industry waste was directly mixed with cow dung in $1: 3$ ( $1 \mathrm{~kg}$ of sample and $3 \mathrm{~kg}$ of cow dung) ratio on dry weight basis in tank $40 \mathrm{~cm}$ height $\times 50 \mathrm{~cm}$ diameter size. Bacillus species $[100 \mathrm{ml}]$ was inoculated to the predecompost tank. The predecomposition tank set up was kept in 30 days. Water was regularly sprinkled and the substrate was regularly turned for 30 days. For preparing the vermicompost, the predecomposition was directly mixed with cow dung in 1:2 (1 kg of predecompost and 2 $\mathrm{kg}$ of cow dung) ratio on dry weight basis in same tank. The substrates were hold 60-80 percentage of moisture content and kept for 24 hrs stabilization. Seventy number of healthy, clitellate Earth worm Eudrilus eugeniae kingberg were introduced in the same tank. After $45^{\text {th }}$ day, the trial tank compost were sieved and col- 
lected for paper industry waste vermicompost. The vermicompost extracts were analyzed for various physico chemical parameters such as $\mathrm{pH}$, electric conductivity, total nitrogen, total phosphorous and total potassium using standard procedures (Mane and Raskar Smitha 2012).

Table 1: The Physico Chemical Parameters of Paper Industry Waste Vermicompost

\begin{tabular}{lll}
\hline SNO & Parameters & At 45 days \\
\hline 1. & $\mathrm{pH}$ & 8.2 \\
2. & Temperature & $34^{\circ} \mathrm{C}$ \\
3. & Electrical conductivity & 0.2 \\
4. & Nitrogen & 0.36 \\
5. & Phosphorous & 1.18 \\
6. & Potassium & 2.65 \\
7. & Carbon & 46 \\
8. & C:N (ratio) & 1.27 \\
\hline
\end{tabular}

Table 2: Enumeration of Microbial Populations of Vermicomposts

\begin{tabular}{llll}
\hline S.NO & Microorganisms & $\begin{array}{l}\text { No of Colony forming units (CFU) of } \\
\text { Commercial vermicompost }\end{array}$ & $\begin{array}{l}\text { No of Colony forming units (CFU) paper industry } \\
\text { waste vermicompost }\end{array}$ \\
\hline 1. & Bacteria & $59.5 \times 10^{6}$ & $85 \times 10^{6}$ \\
2. & Fungi & $9 \times 10^{3}$ & $15 \times 10^{3}$ \\
3. & Actinomyces & $102.5 \times 10^{4}$ & $148 \times 10^{4}$ \\
\hline
\end{tabular}

Table 3: Physico Chemical Parameters of Paper Industry Waste Vermiwash and Vermicompost Extract

\begin{tabular}{llll}
\hline S.NO & Parameters & Vermiwash & Vermicompost extract \\
\hline 1. & $\mathrm{pH}$ & 7.48 & 6.8 \\
2. & Electrical conductivity & 1.2 & 0.5 \\
3. & Temperature & $29^{\circ} \mathrm{C}$ & $30^{\circ} \mathrm{C}$ \\
4. & Nitrogen & 1.65 & 2.38 \\
5. & Phosphorous & 1.15 & 1.95 \\
6. & Potassium & 2.21 & 2.19 \\
7. & Carbon (\%) & 46 & 53.73 \\
8. & C:N (ratio) & 0.03 & 0.04 \\
\hline
\end{tabular}

Table 4: The Growth Parameters of Cluster Bean for 60 Days Pot Culture Study

\begin{tabular}{lllllll} 
& \multicolumn{1}{c}{ Tabowth parameters } & T0 & T1 & T2 & T3 & T4 \\
\hline Germination efficiency & 53 & 77 & 80 & 70 & 70 & 93 \\
Shoot length & $13.8 \pm 6.1$ & $14.3 \pm 6.4$ & $15.1 \pm 6.8$ & $17.1 \pm 7.6$ & $20.1 \pm 8.9$ & $22.4 \pm 11.6$ \\
Root length & $4.9 \pm 1.8$ & $5.4 \pm 2.8$ & $6.1 \pm 3.2$ & $7.9 \pm 4.6$ & $8.1 \pm 5.6$ & $9.4 \pm 6.6$ \\
Total fresh weight & $3.1 \pm 0.2$ & $4.1 \pm 0.1$ & $5.2 \pm 0.2$ & $6.1 \pm 0.3$ & $6.4 \pm 0.2$ & $6.6 \pm 0.4$ \\
Total dry weight & $1.5 \pm 0.2$ & $2.6 \pm 0.1$ & $2.8 \pm 0.1$ & $3.9 \pm 0.1$ & $3.1 \pm 0.1$ & $3.5 \pm 0.1$ \\
Vigour index & 3289 & 4325 & 4220 & 5428 & $5.2 \pm 0.2$ & $3.3 \pm 0.1$ \\
\hline
\end{tabular}

Table 5: The Biochemical Characteristics of Cluster Bean for 60 Days Pot Culture Study

\begin{tabular}{|c|c|c|c|c|c|c|c|}
\hline Biochemical characteristics & T0 & $\mathrm{T} 1$ & $\mathrm{~T} 2$ & T3 & T4 & T5 & T6 \\
\hline Chlorophyll (a) & $0.4 \pm 0.1$ & $1.1 \pm 0.2$ & $1.2 \pm 0.1$ & $1.4 \pm 0.1$ & $1.6 \pm 0.2$ & $1.7 \pm 0.2$ & $1.9 \pm 0.3$ \\
\hline Chlorophyll (b) & $0.3 \pm 0.1$ & $0.4 \pm 0.2$ & $0.2 \pm 0.5$ & $0.4 \pm 0.3$ & $1.6 \pm 0.2$ & $1.6 \pm 0.1$ & $1.9 \pm 0.2$ \\
\hline Total Chlorophyll & $1.4 \pm 0.3$ & $1.6 \pm 0.4$ & $1.9 \pm 1.4$ & $2.1 \pm 0.2$ & $2.3 \pm 0.5$ & $2.6 \pm 0.5$ & $2.9 \pm 0.1$ \\
\hline Anthocyanin & 0.21 & 0.13 & 0.22 & 0.21 & 0.16 & 0.11 & 0.91 \\
\hline
\end{tabular}

The enumeration of microorganisms such as bacteria, fungi and actinomycetes using standard plate count method (Karthika Arumugam et al., 2013). The vermiwash and vermicompost extract were prepared using standard procedures (Seetha Devi et al., 2012). The vermiwash and vermicompost extract were analyzed for various physico chemical parameter such as $\mathrm{pH}$, electrical conductivity, total nitrogen, total phosphorous and total potassium using standard procedures (Ankur Rajpal et al., 2011). Pot culture study was carried out for growth parameters were observed and biochemical characteristics were analyzed for 30 days and 60days intervals of pot culture study of Cluster bean

\section{Results and discussion}

The physico chemical parameters of vermicompost were given table 1 . The $\mathrm{pH}$ of the vermicompost 8.2 , the temperature was $34^{\circ} \mathrm{C}$, the electrical conductivity was 0.2 , the organic carbon was 46 , the total nitrogen was 0.36 , the total phosphorous was 1.18 , total potassium was 2.65 and the total $\mathrm{C}: \mathrm{N}$ (Ratio) of the vermicompost 1.27. Antony et al., (2015) reported the vermicompost of paper waste using Eudrilus eugeniae were the physico chemical parameters such as $\mathrm{pH}$ (7.7), Phosphorous (0.06), Potassium
(0.39) and Moisture was (5\%) (Muddasir Basheer and Agrawal 2013) also reported the vermicompost of paper waste using Eudrilus eugeniae were the physico chemical parameter $\mathrm{pH}$ (7.6.).

The enumeration of microorganisms (Bacteria, Fungi, and Actinomycetes) from 45 days worked vermicompost using Eudrilus eugeniae. The organisms such as Bacteria was $\left(85 \times 10^{6}\right)$ Fungi $\left(15 \times 10^{3}\right)$ and Actinomycetes $\left(148 \times 10^{4}\right)$. Karthika Arumugam et al., (2013) studied the enumeration of microorganisms vermicomposting using after 45 days worked was such as Bacteria, Fungi, and Actinomycetes were analyzed. The physico chemical parameters of vermiwash such as $\mathrm{pH}$ was (7.48), Electrical conductivity (1.2), Temperature $\left(29^{\circ} \mathrm{C}\right)$, Nitrogen (1.65), Phosphorous (1.15), Potassium (2.21), carbon (46) and C: N (ratio) was (0.03). Jayanthi and Jayanthi (2014) reported the physico chemical parmeters of vermiwash such as Nitrogen (1.94), Phosphorous (3.40) and Potassium (0.96) were analysed. Tangavel et al., (2003) also reported the organic waste vermicompost using Eudrilus eugeniae vermiwash physic chemical parameters such as $\mathrm{pH}$, Nitrogen, and phosphorous were analyzed.

The growth parameters of Cluster bean, germination efficiency was higher in $\mathrm{T}_{6}(97 \%)$ Lower in $\mathrm{T}_{0}$ (control) $(53 \%)$. The shoot length was higher in $\mathrm{T}_{6}$ (10.2) lower in T0 (control) (13.8). Root length was higher in $\mathrm{T}_{6}$ (9.4) lower in $\mathrm{T}_{0}$ (control) (4.9). Total 
fresh weight was higher in $\mathrm{T}_{6}$ (1.9) lower in $\mathrm{T}_{0}$ (control) (0.3). Total dry weight was higher in $\mathrm{T}_{6}(1.6)$ lower in $\mathrm{T}_{0}$ (control) $(0.1)$. Leaf area index was higher in $\mathrm{T}_{6}(3.9)$ lower in $\mathrm{T}_{0}$ (control) $(0.1)$. Vigour index of Cluster bean was higher in $\mathrm{T}_{6}(6989)$ lower in $\mathrm{T}_{0}$ (control) (3289). Allah Bakhsh Gulshan et al., (2013) Reported the growth parameters of okra plant using Root length (38.6) and Shoot length was (24.8) using various concentration of vermicomposting compared to inorganic fertilizer. Balbhim et al., (2015) also reported the growth parameters of Cluster bean (Cyamopsis tetragonoloba) using fresh weight (2.6), and dry weight (0.44) was using various concentration of vermicomposting compared to inorganic fertilizer.

The bio chemical characteristics of cluster bean chlorophyll a content was higher in $\mathrm{T}_{6}$ (1.9) lower in $\mathrm{T}_{0}$ (control) (0.4). Chlorophyll $\mathrm{b}$ content was higher in $\mathrm{T}_{6}(1.9)$ lower in $\mathrm{T}_{0}$ (Control) (0.3). Total chlorophyll content was higher in $\mathrm{T}_{6}(2.7)$ lower in $\mathrm{T}_{0}$ (control) $(1.4 \pm 0.9)$. Carotenoides content was higher in $\mathrm{T} 6$ (25.7) lower in $\mathrm{T}_{0}$ (control) (7.7). Anthocyanin content was higher in $\mathrm{T}_{6}$ (0.2) lower in $\mathrm{T}_{0}$ (control) (0.9). Mohamad Oma Albasha et al., (2015) reported the biochemical characteristics of chlorophyll a, chlorophyll $\mathrm{b}$ and total chlorophyll were estimated the brinjal plant. Kamal Lochan Barmer et al., (2013) also reported the biochemical parameters of using Chlorophyll a (1.2), Chlorophyll b (1.9), Carotenoids (11), Anthocynanine (2.7). Sivakumar and Rajan (2014) reported the bio chemical parameters of cluster bean such as chlorophyll a, chlorophyll $\mathrm{b}$, total chlorophyll carotenoids and anthocyanin.

\section{Conclusions}

The present study was concluded that the earthworm Eudrilus eugeniae kingberg is more efficient in bioconversion of paper industry wastes vermicompost, vermiwash and vermicompost extract were using various concentration of pot culture study of Brinjal (60 days) was higher in growth parameters and it is acts as an excellent base for the establishment and multiplication of beneficial and symbiotic microbes. It being a natural means of soil fertility management strategy for sustainable agriculture.

\section{References}

[1] Allah Bakhsh Gulshan., Hafiz Muhammad Saeed., Shazia Javid., Tooba Meryem., Muhammad Imran Atta and Muhammad Aminud-din (2013) Effects of animal manure on the growth and development of OKRA, (Abelmoschus esculentusl) ARPN Journal of Agricultural and Biological Science 8 (3) : 213 - 218 .

[2] Ankur Rajpal., Renu Bhargava and Copra (2011) Stabilization of anaerobic digester sludge through vermicomposting. Journal of Applied and Natural Science, 3 (2): $232-237$.

[3] Antony V., Vignesh, M and Vignesh, V (2015) Utilization of vermicomposting of organic waste for plant growth. International Journal of Pharma and Bio Sciences 6 (1): 326 - 332 .

[4] Balbhim, L. Chavan., Mangesh, M., Vedpathak and Bhimashankar, R. Pirgonde (2015) Effects of organic and chemical fertilizers on cluster bean (Cyamopsis tetragonolobus). European Journal of Experimental Biology, 5 (1): 34 - 38.

[5] Gajalakshmi, S and Abbasi, S.A (2002) Effect of the application of water hyacinth compost vermicompost on the growth and flowering of Crossandra undulaefolia and on several vegetables. Bioresource Technology in Press, $137-143$.

[6] Jayanta Mistry., Ambika Prasad Mukhopadhyay., Gopinath Baur (2015) Status of NPK in vermicompost prepared by two common weed and two medicinal plants. Journal of Advanced Studies in Agricultural, Biological and Environmental Sciences, 2 (1) : 2394 2606.

[7] Jayanthi and Jayanthi (2014) Bioconversion of ficus religlosa in to eco-friendly manure by using epigic earthworm Eisenia foetida Indian streams research journal 4 bioconversion of ficus religlosa in to eco-friendly manure by using epigic earthworm Eisenia foetida, Indian Streams Research Journal 4 (10): 2 - 3.

[8] Kamal Lochan Barman, Rena Baiman Kalita and Dhruva Kumar Tha (2013) Inductions of resistance in brinjal (solanium melogenal) by aquious extrait of vermicompost againest tusainum wily. Inter- national Journal of Plant Animal and Environmental Science 3 (1): 141-148.

[9] Karthika Arumugam, Vasanthy Muthunarayan, Sathalakshmi Ganesan and Susila Sugumar and Awabana (2013) Dynamics of biological physical and chemical parameters during vermicomposting of market waste mixed with cow dung, International Science ,3 (4) : $187-192$.

[10] Mane, T.T and Raskar Smitha, S (2012) Management of agricultural waste from market yard through vermicomposting. Research Journal of Recent Sciences, 1: 289 - 296.

[11] Mohamad Oma Albasa., Gupta, P and Ramteke, P.W (2015) Management of kichen waste by vermicomposting using earthworm, Eudrilus eugeniae. International Conference Advantages in Agricultural, Biological and Environmental Sciences, 81 - 84 .

[12] Muddasir Basheer and Agrawal, O.P (2013) Management of paper waste by vermicomposting using epigeic earthworm, Eudrilus eugeniae in Gwalior, India. International Journal of current microbiology and applied science 2 (4): $42-47$.

[13] Nirmala Natarajan and Gajendran, M (2014) Vermiconversion of paper mill sludge for recycling the nutrients using earthworm $E u$ drilus eugeniae. IOSR Journal of Environmental Science, Toxicology and Food Technology, 8 (9): $06 \quad-11$. http://dx.doi.org/10.9790/2402-08920611.

[14] Nogales, R., Cifuentes, C and Benítez, E (2005) Vermicomposting of winery wastes a laboratory study. Journal of Environmental Science and Health Part 40 (4): 659 - 673. http://dx.doi.org/10.1081/PFC-200061595.

[15] Seethe Devi, G., Karthika. A., Susila. S and Vasanthi Muthunarayanan (2012) bioconversion of fruit waste into vermicompost by employing Eudrilus enqeniea and Eisenia foetida. International journal of plant animal and environmental science, 2 (4): 245 - 252.

[16] Sivakumar, P. and M.R., Rajan (2014) Effect of zinc electroplating industry effluent residue growth and certain biochemical characteristics of Clusterbean (Cyamopsis tetragonaloba) L.Taub. International Journal of Science and Research, 3 (9): 368 - 370.

[17] Sujit Adhikary (2012) Vermicompost, the story of organic gold.

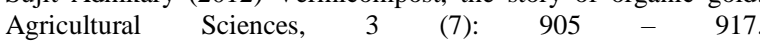
http://dx.doi.org/10.4236/as.2012.37110.

[18] Thangavel, P., Balagurunathan, R., Divakaran, J and Prabhakaran, J (2003) Effect of vermiwash and vermicast extraction soil nutrient status, growth and yield of paddy. Advances of Plant Sciences, 16: 187 - 190. 